\title{
Contents, Vol. 169, 1984
}

\section{Contents Vol. 169,1984}

No. 1 Original Paper Originalarbeiten Travaux originaux

T-Cell Subsets in Acne rosacea Lesions and the Possible Role of Demodex foiliculorum Rufli, T.; Büchner, S.A 1

Determination des sous-populations de lymphocytes circulants dans la dermatite atopique à

Taide d'anticorps monoclonaux

De Maubeuge, J.; Delespesse, G.; Achtenf G.; Servais, G., De Vetter, L.; Gaillaert, N. 6 Mycosis fungoides. Peripheral T Cell Subsets Defined by Specific Monoclonal Antibodies

Valsecchi, R.; Reseghetti, A.; Bontempelli, M.; Frigeni, A.; Cainelli, T 12

Trimethylmethoxyphenyl-Retinoic Acid (Ro 10-1670) and Lymphocyte DNA Synthesis Activity in vitro

Claudy, A.L.; Bouteiller, O. de; Touraine, J.L

Adénome tubulaire apocrine: à propos d'un cas

Kanitakis, J.; Hermier, C; Thivolet, J 23

Skleromyxödem Arndt-Gottron und assoziierte Phänomene

Lang, E.; Zabel, M.; Schmidt, H 29

Tinea capitis in the Elderly. A Report on Two Cases Caused by Trichophyton tonsurans

Moberg, $\mathrm{S} \quad 36$

Is There a Place for ß-Carotene/Canthaxanthin in Photochemotherapy for Psoriasis?

Macdonald, K.; Holti, G.; Marks, J 41

Interferon in the Treatment of Persistent Viral Warts

Gibson, J.R.; Harvey, S.G 47

Urticaria pigmentosa Treated with Oral Disodium Cromoglycate

Lindskov, R.; Lange Wantzin, G.; Knudsen, L.; Søndergaard, 1

No. 2 Original Paper Originalarbeiten Travaux originaux

Vehikelabhängigkeit der Harnstoffpenetration in die menschliche Haut

Wohlrab, W 53

Exploration et thérapeutique des lymphomes cutanés à cellules $\mathrm{T}$

Le, T.; Pierard, G.E.; Pierard-Franchimont, C; Brassinne, M. de la; Lapière, CM. . . 60

Determination of Zinc, Copper, Manganese, and Iron in Blood from Patients with Light-

Sensitive Skin Diseases

Horkay, I.; Teherani, D.K.; Altmann, H.; Krajczár, J 66

The Problem of the Sensitization to Dithiocarbamates in Thiuram-Allergic Patients

Ketel, W.G. van; Berg, W.H.H.W. van den 70

Reduced Graft-versus-Host Reaction of T Cells in Kaposi's Sarcoma: A Possible Prognostic

Indicator

David, M.; Shohat, B.; Morozinski, G.; Feuerman, E.J 76

A Newly Recognized Feature of Ectrodactyly, Ectodermal Dysplasia, Clefting (EEC) Syndrome:

Comedone naevus 
Leibowitz, M.R.; Jenkins, T 80

Pseudomegadactyly. A Unique Presentation of Chronic Granulomatous Paronychia

Mittal, R.L.; Mittal, R 86

Toxic Epidermal Necrolysis Probably Due to Klebsiella pneumoniae Sepsis

Groot, R. de; Oranje, A.P.; Vuzevski, V.D.; Mattau, J.W 88

Facial Hemiatrophy in a Patient with Systemic Scleroderma

Nomura, K.; Yagihashi, Y.; Chiyoya, S.; Sato, S.; Hashimoto, 191

IV

Contents

Bluefarb-Stewart Syndrome - Report of a New Case

Alessi, E.; Sala, F 93

A Case of Epidermodysplasia verruciformis (Lewandowsky-Lutz, 1922) with Skin Cancer:

Histopathology of Malignant Cutaneous Changes

Tanigaki, T.; Endo, H 97

Oral Manifestations of Sweet's Syndrome

Driban, N.E.; Alvarez, M.A 102

Book Reviews · Buchbesprechungen a Livres nouveaux 104

No. 3 Original Paper Originalarbeiten Travaux originaux

Dermatosis of Hairless Rats Fed a Hypomagnesic Diet - Pathology and Immunology

Chavaz, P.; Faucher, F.; Saurat, J.H 105

Subpopulations of T Lymphocytes in Peripheral Blood and in Skin Lesions in Lichen ruber planus

Simon, M., Jr.; Keller, J 112

The Epidermal Merkel Cell is an Epithelial Cell

Saurat, J.H.; Didierjean, L 117

Anti-DNA Antibodies in Blood Serum of Psoriatic Patients

Zlatkov, N.B.; Bozhkov, B.; Nikolov, K.; Dourmishev, A.L 121

Papuloerythroderma (With 1 color plate)

Ofuji, S.; Furukawa, F.; Miyachi, Y.; Ohno, S 125

Porphyria cutanea tarda in Beta-Thalassemia Trait Carriers

Gibertini, P.; Rocchi, E.; Cassanelli, M.; Pietrangelo, A.; Ventura, E

Prurigo pigmentosa Affecting the Forehead

Miyakawa, S.; Kurihara, S.; Nishikawa, T 135

2 Cases of Hereditary Palmoplantar Keratoderma. An Abnormality of Keratohyalin Granules and

Keratin Fibril Formation (With 1 color plate)

Tezuka, T 138

A Case of Hypothyroidism with Bulla Formation

Mochizuki, T.; Tanaka, S.; Watanabe, S 146

Intralesional Chemotherapy for Kaposi's Sarcoma

Brambilla, L.; Boneschi, V.; Beretta, G.; Finzi, A.F 150

Kaposi's Sarcoma after Immunosuppressive Therapy for Bullous Pemphigoid

Scaparro, E.; Borghi, S.; Rebora, A 156

Erratum $\quad 160$

Announcements $\mathbf{a}$ Ankündigungen · Annonces 160

No. 4 Original Paper Originalarbeiten Travaux originaux

Malignant Hidroacanthoma simplex. A Light Microscopic, Ultrastructural, and Immunohis- 
tochemical Study of 2 Cases

Moreno, A.; Salvatella, N.; Guix, M.; Llistosella, E.; Moragas, J.M. de

Malignant Melanoma Associated with Mycosis fungoides

Flindt-Hansen, H.; Brandrup, F 167

Lichen aureus

Büchner, S.A 169

Bleomycin-Induced Raynaud's Phenomenon and Acral Sclerosis

Snauwaert, J.; Degreef, H 172

Contents V

Erythema multiforme - Response to Corticosteroid

Ting, H.C.; Adam, B.A 175

An Assessment of the Novel Antihistamine BW 825C in the Treatment of Chronic Idiopathic Urticaria. A Placebo-Controlled Study

Gibson, J.R.; Harvey, S.G.; Barth, J.H.; Moss, M.Y.; Burke, C.A 179

Phlebotomy Treatment in Porphyria Cutanea Tarda Combined with B-Thalassaemia

Adjarov, D.; Donov, M.; Ivanov, E.; Naidenova, E 184

Failure of Mexiletine to Relieve Severe Pruritus

Hägermark, Ö.; Anderson, P.; Nordlind, K 188

Trichophyton-rubrum-lnîecteá Toenails Treated with Ketoconazole and Partial Nail Avulsion

Kavli, G.; Midelfart, K.; Moseng, D.; Stenvold, S.E.; Falk, E.S.; Nilssen, J.W.; Volden, G. 191

Mycosis fungoides with Monoclonal Gammopathy, Hypereosinophilia, and Hyper-IgE

Palermo, A.; Moretti, S.; Difonzo, E.M.; Fattorossi, A 194

An Epidemic Study of Molluscum contagiosum. Relationship to Swimming

Niizeki, K.; Kano, O.; Kondo, Y 197

The Interesting Case Der interessante Fall · Un cas intéressant

Polyarthritis with Atypical Keratotic Nodular Dermatosis or Polyarthritis with Multiple

Keratoacanthoma. A Case Report

Mittal, R.; Mittal, R.L.; Chopra, A.; Gupta, K 199

An Early Picture of Pagetoid Reticulosis

Naito, Y.; Kawatsu, T.; Yamamura, T.; Kitano, Y 203

Monoclonal IgG Immunoglobulinemia with Subsequent Myeloma in Psoriatic Arthritis

Peltonen, L.; Nikoskelainen, E.; Kätkä, K.; Tyrkkö, J 207

Prurigo nodularis Associated with Malabsorption

Suárez, C; Pereda, J.M.; Moreno, L.M.; García-Gonzáles, F.; Gómez-Orbaneja, J. . . 211

Letter to the Editor Brief an die Redaktion · Lettre à la redaction

Nocardia brasiliensis Lymphocutaneous Syndrome in a Patient with Lymphosarcoma

Wishnitzer, R.; Berrebi, A.; Walde, J. von der; Miskin, A.; Frumkin, A 215

Retinoid Symposium

New Trends in Research and Therapy. Geneva, September 20-22, 1984. Abstracts

Editor: J.-H. Saurat, Geneva 217

No. 5 65. Jahresversammlung der Schweizerischen Gesellschaft für Dermatologie und Venereologie

14. und 15. Oktober 1983 in Bern 65e Reunion annuelle de la Société Suisse de Dermatologie et de Vénéréologie

14 et 15 octobre 1983 à Berne

Klinische Demonstrationen - Presentation de cas cliniques 
Klinische Demonstrationen der Dermatologischen Klinik der Universität Bern (mit 1 Farbtafel)

Krebs, A.; Zala, L.; Jenni, C; Roduner, J.; Hunziker, T. und Mitarbeiter 265

Demonstrationen der Dermatologischen Universitätsklinik Zurich

Wüthrich, B.; Eichmann, F.; Zortea-Caflisch, C; Gilardi, S.; Schnyder, U.W

Presentation de cas cliniques de la Clinique Universitaire de Geneve

Chavaz, P.; Polla, L.; Saurat, J.-H.; Poffet, D.; Harms, M.; Didierjean, L.; Vamenzind, M.;

Polla, L.; Schifferli, J.; Tissot, J.D 282

VI Contents

Demonstrationen der Dermatologischen Universitätsklinik Basel

Rufli, T.; Büchner, S 291

Cl Inhibitor Functional Activities in Hereditary Angioedema Plasma of Patients under

Therapy with Attenuated Androgens

Späth, P.J.; Wüthrich, B.; Butler, R 301

Steroid Sulfatase $=$ Aryl Sulfatase C? Chromatographic and Electrophoretic Properties in

Extracts from Placental Microsomes and Skin Fibroblasts

Weiss, H.; Meyer, J.C.; Grundmann, H 305

Original Paper Originalarbeiten Travaux originaux

$\mathrm{M}$ ulticentric Reticulohistiocytosis

Guillen, C; Fortea, J.M.; Serrano, G.; Martorell, M.A.; Cogollos, E.; Alegre, V.; Aliaga, A. 311

Secretory IgA in Schönlein-Henoch Purpura

Kaneko, F.; Mori, N.; Miura, Y 318

Announcement - Ankündigung - Annonce 324

No. 6 Original Paper · Originalarbeiten Travaux originaux

T Cell Subsets and Macrophages in Lichen planus. In situ Identification Using Monoclonal

Antibodies and Histochemical Techniques

Buechner, S.A 325

Characterization of Cellular Infiltrates in Skin Lesions of Atopic Eczema by Means of Mono clonal Antibodies

Rocha, C; de Maubeuge, J.; Sarfati, M.; Song, M.; Delespesse, G 330

Autoantibodies to Epithelial Cells (Intercellular Substance) and Their Correlation with Clin ical Activity of Pemphigus vulgaris

Golan, D.; Gilhar, A.; Shmuel, U.; Moshkowitz, M 339

Alkaline Phosphatase Positive Lymphoma

Geerts, M.-L.; Burg, G.; Schmoeckel, C; Braun-Falco, 0342

Oxatomide in the Treatment of Pruritus senilis. A Double-Blind Placebo-Controlled Trial

Dupont, C; de Maubeuge, J.; Kotlar, W.; Lays, Y.; Masson, M 348

A Variant of Encephalomeningocele: Heterotopic Brain Tissue on the Scalp

Tanii, T.; Hamada, T 354

Congenital Fistulas of the Lower Lip. Radiographic Evaluation

Ortega-Resinas, M.; Sanchez-Conejo-Mir, J.; Sanchez-Pedreño-Guillen, P.; Camacho-

Martinez, F 359

The Interesting Case Der interessante Fall Un cas intéressant

Skin Metastasis of Adenocarcinoma of the Urinary Bladder

Takematsu, H.; Obata, M.; Sato, A.; Miura, T 363

Author Index 365 
Subject Index 367

Suppl. 1 International Symposium on Bifonazole Copenhagen, June 21-23, 1984 Guest Editor: H. Rieth, Hamburg

Fig. 1-6.1 Diffuse, brownish-red, erythroderma-like lesions are seen on back and extensor surfaces of upper arms. Posterior parts of axillae are spared with a clear border. 2 Big furrows are spared from diffuse lesions on abdomen. In peripheral parts and neighborhoods of diffuse lesions, assembled or confluent papules are observed. 3 Diffuse lesions on chest are composed of assembly of small macules. 4 Papules are seen scattered on flexor surfaces of forearms, and assembled or confluent on upper arms. Cubital fossae are not involved. 5 Hyperkeratosis is seen on palms. 6 Red papules on left upper arm appearing on an exacerbation. 